\title{
PENGARUH UKURAN PASIR TERHADAP KINERJA BOILER UNIT 1 PLTU PULANG PISAU
}

\author{
Karno'), Achmad Kusairi Samlawi ${ }^{2}$ \\ ${ }^{1,2}$ Program Studi Teknik Mesin \\ Fakultas Teknik Universitas Lambung Mangkurat \\ Jl. Akhmad Yani Km 36 Banjarbaru, Kalimantan Selatan, 70714 \\ e-mail: karno_safir@yahoo.com
}

\begin{abstract}
The use of sand in the cfb boiler function as a coal burner which enters the combustion chamber. Sand in the combustion chamber is lined up and coal enters the combustion chamber. With the entry of coal into the furnace fluidization occurs, where the heat in the sand burns coal that hovers, so that the heat that arises is used to heat the water in the boiler tubes. The remaining coal combustion (ash) wil float/fly inhaled by IDF air. Sand movement is expeted to only always bubbling up ang down in the furnace area only so that complete combustion occurs and the boiler is reliable. Because the bubbling is influenced by air pressure, coal quality, which can cause friction between material (sand and coal) and refractory giving rise to abrasives on refractory. If refractory is abrasive it can cause abrasive on the tube water wall boilers, tube cyclones so that boiler performance will decrease. The use of sand that is not clear is one of the causes of refractory damage in cfb type boilers. So that the cfb boiler remains reliable, the use of sand must be in accordance with the type and size according to the particular boiler.
\end{abstract}

Keywords: Sand, Boiler, Reliability CFB

\section{PENDAHULUAN}

Boiler/ketel uap jenis CFB ini tidak lepas dari permasalahan-permasalahan diantaranya permasalahan operasi serta akibat kesalahan pemilihan material, fabrikasi, ketidak sesuaian dengan kondisi kerjanya, yang menjadi penyebab rusaknya komponen atau peralatan pembangkit.

Resiko kegagalan bisa terjadi bila pola operasi serta karakter batubara dan pasir kurang tepat, dapat mempercepat abrasive/keausan dan kegagalan yang extrim yang bisa mengakibatkan retak atau pecahnya refactory dan bahkan rusaknya tube boiler.Kerusakan akibat kebocoran tube boiler sering terjadi beberapa kali di PLTU Pulang Pisau, penyebab yang mungkin terjadi akibat pemanfaat bed material/pasir kwarsa yang salah sehingga menyebabkan umur peralatan tidak bertahan lama. Pada dasarnya PLTU Pulang Pisau belum pernah melakukan assestment secara detail untuk mengetahui potensi kerusakan yang terjadi pada boiler di PLTU Pulang Pisau, sehingga penulis mengangkat judul " Pengaruh ukuran pasir terhadap Kinerja Boiler unit 1 PLTU Pulang Pisau".

\section{Penggunaan Pasir Kwarsa/Silika pada Boiler CFB}

Boiler fluidisasi memberikan kehandalan dan performa yang efisien jika dioperasikan dengan benar. Prinsip pengoperasian fluidisasi adalah keseragaman atau terjadinya fluidisasi yang merata pada pasir. Dalam ruang bakar, fluidisasi terdiri dari nozzle yang mendistribusikan udara agar pasir silika dapat bergejolak pada dinding yang dilapis refractory. Udara fluidisasi didapat dari fan tekan. Pasir silika digunakan untuk bed material. Faktor yang dominan dari pasir adalah ukuran dan berat jenisnya. 
Teori fluidiasi yaitu dengan mengalirkan sejumlah cairan atau gas yang cukup melalui partikel yang ditempatkan pada bed maka suspensi partikel terbentuk dan mulai bertindak seperti cairan. Hal ini dimungkinkan untuk memfluidakan partikel padat dengan cair. Gaya drag yang bekerja pada partikel dari aliran gas harus setidaknya di kisaran yang sama dengan gaya gravitasi untuk mendapatkan fluidisasi. Kecepatan terendah yang diperlukan untuk mendapatkan fluidisasi (membuat semua partikel disuspensi oleh gas) disebut kecepatan fluidisasi minimum (umf). Jika kecepatan gas lebih besar dari umf fluidized bed mulai berperilaku berbeda dan masuk ke rezim yang berbeda, tergantung pada seberapa banyak peningkatan kecepatannya. Dengan kecepatan tinggi fluidized bed akan mengembang karena meningkat jumlah gas antara partikel. Konsentrasi partikel diukur sebagai berat jenis suspensi, $\rho c$ $[\mathrm{kg} / \mathrm{m} 3]$

Dalam fluidized bed dapat terjadi fraksional partikel dengan ukuran yang berbeda. Hal ini disebabkan oleh kombinasi perilaku dari dua gaya pada partikel (gaya drag), Fd, yang disebabkan oleh aliran udara fluidisasi dan gaya gravitasi, Fg. Fd adalah tergantung secara linear pada luasan partikel, seperti yang dijelaskan pada Pers. 1 (Wolfram Alpha). Fg secara linear tergantung pada volume partikel, seperti dijelaskan oleh Pers. 2, menurut hukum gerak Newton kedua.

$$
\begin{aligned}
& \mathrm{Fd}=1 / 2 \mathrm{~cd} \cdot \rho \cdot \mathrm{u}^{2} \cdot \mathrm{A} \\
& \mathrm{Fg}=\rho \cdot \mathrm{V} \cdot \mathrm{g}
\end{aligned}
$$

Dimana cd adalah koefisien drag, yang konstan untuk partikel berbentuk sama, $\rho$ adalah densitas partikel, $u$ adalah perbedaan kecepatan antara gas (udara) dan partikel, $\mathrm{A}$ adalah luas partikel, $\mathrm{V}$ adalah volume partikel dan $\mathrm{g}$ adalah konstanta gravitasi. Jika partikel cukup bulat, dengan meningkatnya ukuran partikel gaya gravitasi meningkat lebih dari peningkatan gaya drag. Oleh karena itu partikel yang lebih besar cenderung bertahan sedangkan yang partikel lebih kecil lebih mungkin bergerak dengan aliran gas. Untuk CFB, ini menghasilkan ukuran partikel rata-rata di bagian atas riser menjadi lebih kecil dari ukuran partikel rata-rata di bagian bawah.

PLTU Pulang Pisau menggunakan Boiler jenis CFB yang bekerja dengan prinsip mensirkulasikan kembali batubara yang tidak terbakar dari Cyclone kembali menuju furnace secara kontinyu selama proses pembakaran. Pasir difluidisasikan oleh udara berdebit tinggi menggunakan primary air fan melalui nozzle pada bagian dasar furnace. Boiler jenis CFB menggunakan pasir sebagai media penyimpanan panas untuk membakar batubara low range. Kalor hasil pembakaran batubara diserap untuk memanaskan pipa-pipa yang ada di dalam boiler. Proses pembakaran yang terjadi di ruang bakar (furnace) ini pada temperature $850^{\circ} \mathrm{C}-950^{\circ} \mathrm{C}$. Bed material yang digunakan berupa pasir silika (silica sand) sesuai manual book size $0-5 \mathrm{~mm}$.

Dengan mengalirkan sejumlah gas dengan kecepatan fluidized melalui partikel yang ditempatkan pada bed maka suspensi partikel terbentuk dan mulai bertindak seperti cairan. CFB boiler menggunakan prinsip inersia thermal dari material yang sengaja dimasukkan ke furnace (disebut sebagai bed materials) yang biasanya berupa partikel pasir. Keberadaan material yang berupa partikelpartikel dengan kecepatan tinggi ini dapat mengakibatkan terjadinya abrasive pada dinding furnace. Tingkat abrasive pada dinding furnace dipengaruhi oleh kecepatan dan pola aliran serta bentuk laluan partikel.

Proses penggunaan pasir dan bahan bakar yang digunakan di dalam boiler CFB sederhana. 


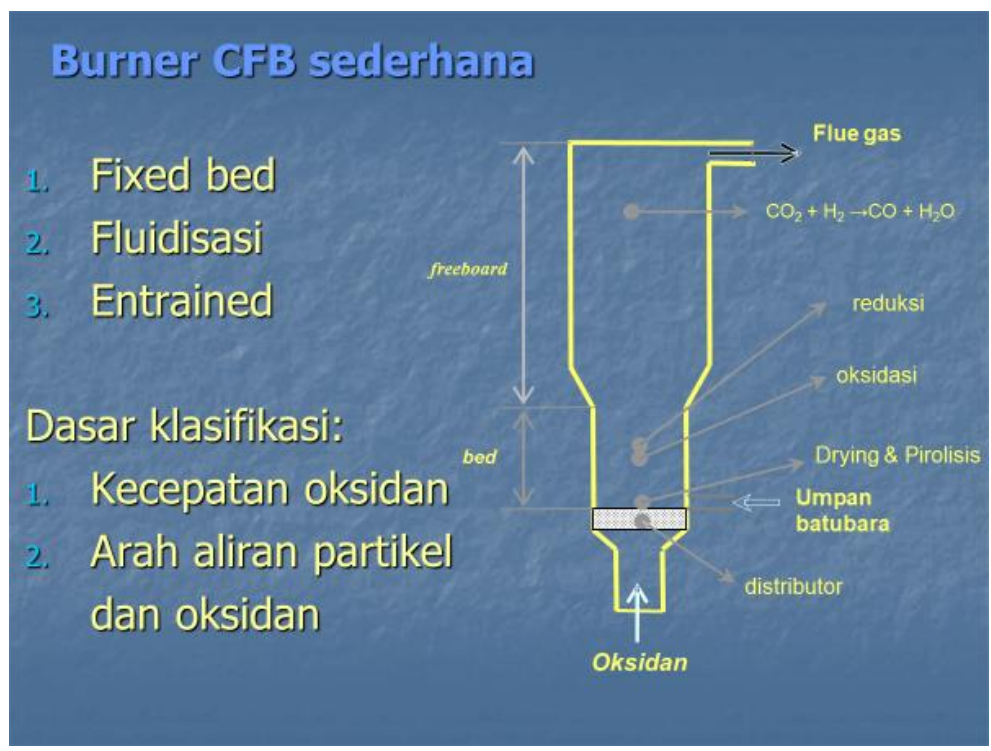

Gambar 1. Proses CFB sederhana

Pasir merupakan media penyalur panas terhadap bahan bakar batubara yang akan membakar batubara di ruang bakar boiler jenis CFB. Jenis dan ukuran pasir sagat berpengaruh terhadap kehandalan Boiler CFB yang berkaitan dengan pengoperasian dan umur (lifetime) boiler.

Secara sederhana proses pergerakan pasir pada boiler CFB Gambar 1. dijelaskan bahwa ada 3 kategori proses fluidisasi pasir pada boiler CFB yaitu:

1. Fixed bed

Umpan partikel dan fluida (gas) masuk ke bed. Gas dapat melewati partikel tanpa mengganggu posisi partikel di bed.

\section{2. $\quad$ Fluidisasi}

Kecepatan gas dinaikkan, partikel mulai bergerak, volume bed berkembang sampai pergerakan partikel dan gas sama (uniform) membentuk aliran dua fasa dan berkelakuan seperti fluaida disebut fluidisasi. Jika fluidisasi ini kecepatannya dinaikkan akan membentuk bubble. Bubble dipertahankan selalu berukuran kecil.

\section{Entrained}

Pada posisi bubbling kecepatan dinaikkan semua partikel akan terangkat ke atas dan mulai meninggalkan bed, disebut entrained (terlempar). Terjadinya entained ini yang akan memperbesar tingkat abrasive refractory maupun abrasive tube.

Pengaruh ukuran pasir terhadap fluidisasi berdasarkan parameter distribusi pasir (volume fraction), kecepatan udara maupun kecepatan pasir dan juga tekanan. Dilihat bahwa semua kasus menunjukkan perubahan distribusi pasir berdasarkan waktu, hanya saja antar kasus memiliki ketinggian bed material serta pola fluidisasi yang berbeda. Semakin kecil ukuran pasir yang digunakan maka ketinggian bed material semakin tinggi. Sebaliknya apabila ukuran (size) pasir terlalu besar maka proses fluidisasi berjalan lambat dengan tanpa menaikkan tekanan dan flow udara primer. Maka penting untuk diketahui pengaruh ukuran pasir terhadap fluidisasi serta untuk mengetahui ukuran pasir yang paling sesuai pada suatu CFB boiler. Normalnya ketinggian bed material yang ideal adalah sekitar $5-10 \%$ dari ketinggian furnace. 


\section{Draft System}

Draft system adalah perbedaan tekanan atmosfer dengan tekanan statis di ruang bakar, saluaran gas buang serta stack yang menimbulkan laju aliran tertentu. Secara umum, draft system mempunyai peranan penting dalam sistem pembangkit antara lain:

1. Pengirim udara di ruang bakar untuk memenuhi kebutuhan pembakaran antara udara dan bahan bakar.

2. Membuang gas bekas pembakaran dari ruang bakar dan mengalirkannya ke stack hingga keluar ke atmosfer dengan lancar.

3. Menurunkan polusi dari abu (mempermudah abu masuk ke tempat penampungan).

Dalam darft system tersebut terdapat beberapa fan yang sangat penting dalam proses pembakaran di dalam ketel agar terjadi keseimbangan antara udara dan bahan bakar agar terjadi efisien dalam penggunaan bahan bakar. Fan tersebut adalah : Kipas udara primer/PAF, Kipas udara sekunder/SAF dan Kipas penghisap udara/IDF.

1. Primary air fan

Primary Air Fan (PAF) berfungsi sebagai fluidisasi/mencampur bahan bakar dan suplai oksigen yang cukup untuk proses pembakaran di dalam furnace.

\section{Secondary air fan}

Fungsi : sebagai pengaduk utama dengan sistem udara tekan, mengaduk antara pasir dan batubara yang telah terbakar di dalam furnace agar tetap melayang-layang.

\section{Induced draft fan}

Induced Draft Fan adalah kipas yang menghisap udara dari dalam ketel keluar menuju stack, yang menghasilkan tekanan negatif pada ketel, untuk menjaga sirkulasi udara pembakaran dalam ketel tetap normal yaitu dari Secondary Air Fan (SAF) sebagai pemasok udara pembakaran dengan IDF sebagai penghisap gas buang terjadi seimbang.

\section{Perbedaan Ketel CFB dengan Ketel PC}

Ketel tipe CFB ini mempunyai keunggulan jika dibanding dengan ketel jenis $P C$. Tabel 1. dibawah merupakan perbedaan kelebihan dan kekurangan antara ketel tipe CFB dan ketel PC. 
Tabel 1. Perbandingan ketel CFB dengan ketel PC

\begin{tabular}{|c|c|c|}
\hline No & Ketel CFB & Ketel PC \\
\hline 1 & $\begin{array}{c}\text { Temperatur pembakaran di ruang bakar } \\
\text { rendah }( \pm 800 \quad \mathrm{C})\end{array}$ & $\begin{array}{c}\text { Temperatur pembakaran di ruang } \\
\text { bakar tinggi }(\geq 1000 \mathrm{C})\end{array}$ \\
\hline 2 & $\begin{array}{c}\text { Kandungan Sox dan Nox yang rendah } \\
\text { karena menggunakan kapur }\end{array}$ & $\begin{array}{c}\text { Kandungan Sox dan Nox tinggi karena } \\
\text { tidak menggunakan kapur }\end{array}$ \\
\hline 3 & $\begin{array}{c}\text { Ukuran batu bara masuk ke ruang bakar } \\
( \pm 6 \mathrm{~mm})\end{array}$ & $\begin{array}{c}\text { Ukuran batubara masuk ke ruang } \\
\text { bakar dalam bentuk halus (serbuk) }\end{array}$ \\
\hline 4 & $\begin{array}{c}\text { Batu bara yang digunakan nilai kalornya } \\
\text { rendah }\end{array}$ & Nilai kalor batubara tinggi \\
\hline 5 & $\begin{array}{c}\text { Menggunakan panel evaporator dan } \\
\text { untuk pemanfaatan radiasi panas dari } \\
\text { pembakaran }\end{array}$ & $\begin{array}{c}\text { Tidak menggunakan panel evaporator } \\
\text { dan panel super heater }\end{array}$ \\
\hline 6 & $\begin{array}{c}\text { Pengunaan start up burner tidak } \\
\text { tergantung dari beban (MW) tetapi } \\
\text { temperature ruang bakar }\end{array}$ & $\begin{array}{c}\text { Penggunaan start up burner tergantung } \\
\text { beban }\end{array}$ \\
\hline
\end{tabular}

\section{Proses Kerja Sistem Bahan Bakar}

PLTU Pulang Pisau dalam operasinya menggunakan bahan bakar HSD dan batubara. Untuk start-up menggunakan bahan bakar HSD. Setelah temperatur furnace mencapai $400^{\circ} \mathrm{C}-500^{\circ} \mathrm{C}$, bahan bakar batubara mulai di campurkan (mix HSD dan Coal). Bila pembakaran terjadi sempurna (temperature area furnace merata) maka bahan bakar HSD bisa dimixing dengan batubara. Setelah temperature furnace mencapai $850^{\circ} \mathrm{C}$ maka penggunaan $\mathrm{HSD}$ bisa distop dan pembakaran dilanjutkan menggunakan batubara sampai ke pembebanan dan pengoperasian normal.

\section{METODOLOGI PENELITIAN}

Penjelasan pada Metodologi penelitian ini diuraikan menjadi sub bab yaitu fokus penelitian dan tempat, diagram alir penelitian, data yang diperlukan, cara pengumpulan informasi serta peralatan yang diperlukan berupa:

\section{Lokasi Penelitian}

Lokasi penelitian ini fokus pada pengamatan terhadap ukuran pasir yang tepat untuk Boiler PLTU Pulang Pisau unit 1 dengan memperhatikan dampak pada performance material water wall tube boiler. Penelitian ini didukung dengan dilakukan pemeriksaan Thickness Test pada area tube yang mengalami kerusakan. Dengan menggunakan metode tersebut, dapat dilakukan pengamatan dan penelitian penyebab rusaknaya refractory dan tube yang diakibatkan oleh pemakaian jenis dan ukuran pasir (bed material) yang kurang tepat.

\section{Keperluan Data}

Data-data yang diperlukan untuk menunjang penelitian ini adalah berupa:

1. Data primer

Data primer adalah data yang didapatkan oleh peneliti secara langsung melalui sumbernya. Dapat berupa observasi langsung, memberikan kuisioner, dan Tanya jawab langsung. Untuk mendapatkan data primer ini adalah dengan melakukan observasi ke lapangan sehingga bisa melakukan pengamatan langsung dan bertanya langsung kepada petugas yang memahami tentang halhal yang berkaitan dengan permasalahan yang diperlukan. 
2. Data sekunder

Data ini diperoleh secara mebaca buku atau sumber yang sudah terbukti kebenaranyya untuk dipakai sebagai acuan untuk mendukung penyusunan penelitian ini. Data sekunder didapat melalui model membaca baik berupa buku, jurnal, maupun media cetak dan elektronik yang sumbernya bisa di percaya.

3. Pengumpulan informasi dan data

Informasi dan data yang didapat merupakan sarana penunjang untuk penyusunan penelitian ini. waktu mendapatkan informasi dan pengumpulan data, maka perlu diketahui caranya berikut :

a. Informasi dan data langsung

Informasi dan data langsung didapatkan dari pemantauan pada objek yang akan dilakukan penelitian. Untuk mendapatkan informasi dan data ini dilakukan penelitian melalui pengamatan langsung dan tanya jawab:

1. Observasi ini untuk mengumpulkan data secara langsung melakukan observasi dan pengamatan dilapangan guna mengetahui titik permasalahan yang terjadi untuk dilakukan penelitian atau kajian.

2. Wawancara dilakukan tanya jawab dengan sumber terpercaya untuk mendapatkan data yang berkaitan dengan obyek penelitian.

b. Informasi dan data tidak langsung

Informasi dan data tidak langsung merupakan sumber yang diperoleh untuk mempermudah dalam melaksanakan penelitian ini. Data tidak langsung ini dilakukan dengan cara mempelajari buku-buku yang berkaitan dengan obyek penelitian:

1. Untuk mendapatkan teori-teori yang berkaitan dengan obyek penelitian guna menunjang peneliti didalam melakukan kajian ini diperlukan kajian pustaka.

2. Data historis yang diperlukan dari perusahaan, yang berupa logsheet, maupun catatan-catatan penting lainnya. 


\section{Diagram Alir Penelitian}

Langkah-langkah dalam penelitian ini dapat di lihat dalam Gambar 2.

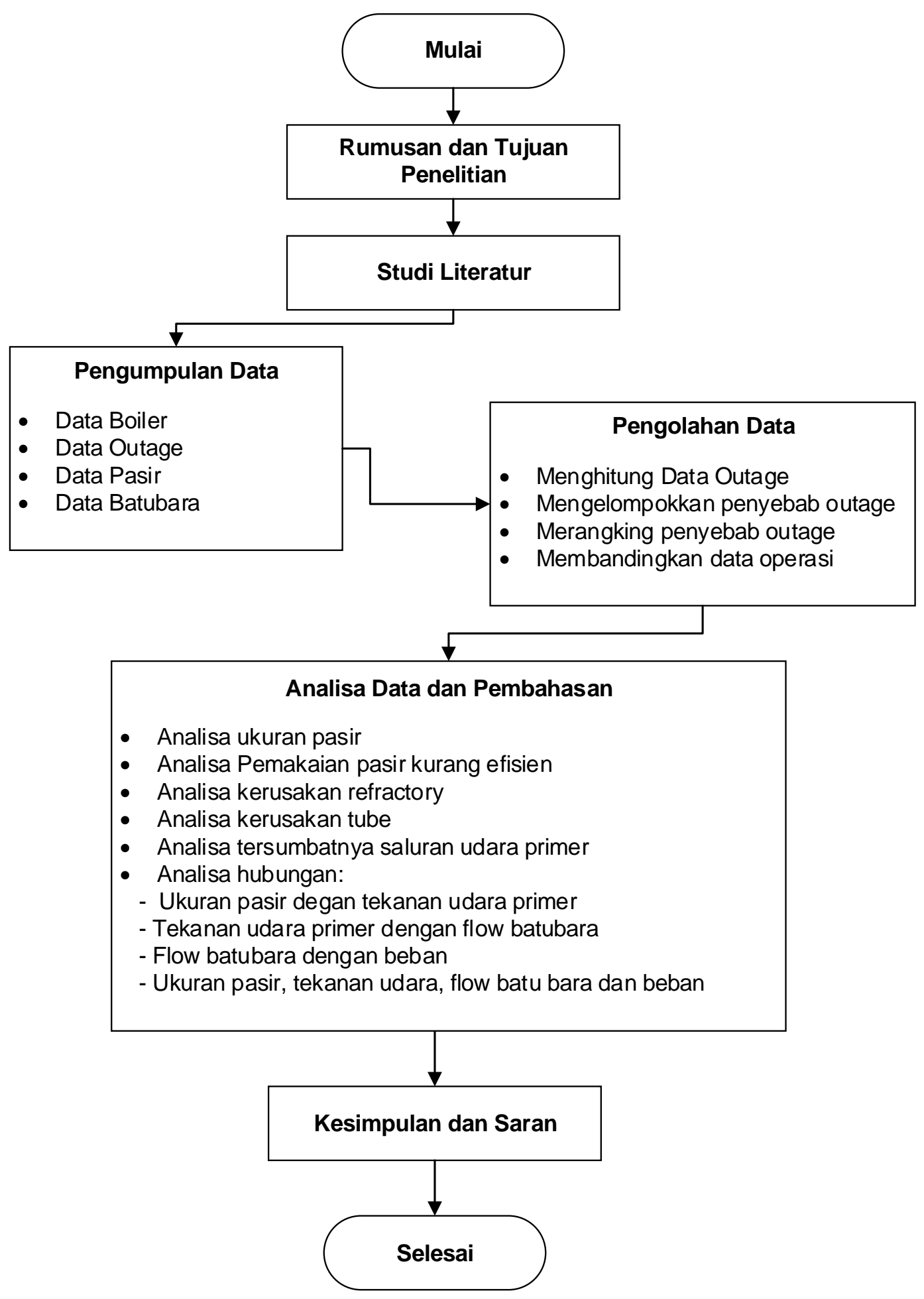

Gambar 2. Diagram Alir Penelitian 


\section{HASIL DAN PEMBAHASAN \\ Pengoperasian Boiler}

Dalam pengoperasian boiler mempunyai karakteristik masing-masing. Oleh karena itu dalam mengoperasikan suatu boiler, umumnya kita mengacu pada manual book yang diterbitkan oleh pabrik pembuatnya agar tahu batasanbatasan parameter yang diijinkan.

Selain mengacu pada manual book tentunya kita juga harus tahu prosedur pengoperasian. Peran manual book dan Standing Operation Prosedure (SOP), sangatlah penting dalam melakukan/mengoperasikan peralatan.Tentunya sebelum mengoperasikan peralatan kita juga perlu mengetahui spesifikasi peralatan tersebut. Tabel 2 merupakan data spesifikasi boiler PLTU Pulang Pisau yag menunjukkan kapasitas dan batasan kerja yang diijinkan dalam pengoperasian.

Tabel 2. Spesifikasi Boiler PLTU Pulang Pisau \# 1 \& 2

\begin{tabular}{|c|c|c|c|}
\hline No & Item & Unit & BMCR \\
\hline 1 & Rated evaporation capacity & $\mathrm{t} / \mathrm{h}$ & 270 \\
\hline 2 & Rated steam temperature & ${ }^{\circ} \mathrm{C}$ & 540 \\
\hline 3 & Rated steam presure & $\mathrm{MPa}$ & 9.81 \\
\hline 4 & Feedwater temperature & ${ }^{\circ} \mathrm{C}$ & 215 \\
\hline 5 & Boiler exhaust flue gas temperature & ${ }^{\circ} \mathrm{C}$ & 140 \\
\hline 6 & Steam presure & $\mathrm{MPa}$ & 10.8 \\
\hline 7 & Boiler efficiency & $\%$ & 89.5 \\
\hline
\end{tabular}

Sedangkan Tabel 3 dibawah merupakan spesifikasi bahan bakar batubara yang bisa digunakan untuk boiler PLTU Pulang Pisau yang sesuai dengan manual book. Untuk mengoperasikan boiler secara umum terbagi 3 kelompok yaitu: Start dingin, start hangat dan atart panas. Sebelum melakukan pengoperasian boiler tersebut maka petugas harus tahu dan faham tentang Stadart Operation Procedur (SOP).

Tabel 3. Spesifikasi Batubara PLTU Pulang Pisau

\begin{tabular}{|c|c|c|c|c|}
\hline No & Item & Symbol & unit & Design coal \\
\hline 1 & Total Moisture & Mt.ar & $\%$ & 35 \\
\hline 2 & Air-dried moisture & Mad & $\%$ & 18 \\
\hline 3 & As received ash content & Aar & $\%$ & 5 \\
\hline 4 & Dry ash-free basis volatile content & VdaF & $\%$ & 58.33 \\
\hline 5 & High calorific value & Qnet.ar & $\mathrm{MJ} / \mathrm{k}$ & 4000 \\
\hline 6 & As received basis carbon & $\mathrm{Car}$ & $\%$ & 40.92 \\
\hline 7 & As received basis hydrogen & $\mathrm{Har}$ & $\%$ & 3.42 \\
\hline 8 & Received basis oxygen & Oar & $\%$ & 13.9 \\
\hline 9 & As received basis nitrogen & Nar & $\%$ & 0.68 \\
\hline 10 & As received total sulfur & St.ar & $\%$ & 1.08 \\
\hline 11 & Deformation temperature & DT & ${ }^{\circ} \mathrm{C}$ & $>1050$ \\
\hline 12 & Softening temperature & ST & ${ }^{\circ} \mathrm{C}$ & $>1100$ \\
\hline 13 & Melting temperature & FT & ${ }^{\circ} \mathrm{C}$ & $>1200$ \\
\hline
\end{tabular}

\section{Analisa Ukuran Pasir}

Dengan mengacu pada TOR tanggal 04/07/2018 tersebut dirasa kurang tepat maka dibuatlah Notulen Rapat tertanggal 15/08/2018 yang disepakati acuan ukuran pasir kembali ke TOR tanggal 15/02/2018. 
Batasan ukuran pasir yang kecil tersebut mengacu pada data yang dilakukan pengujian dimana pasir yang kecil cenderung melayang dan terbang ikut menjadi abu. Data tersebut kami lakukan pengukuran menunjukkan bahwa:

1. Pengadaan awal terdapat ukuran $<0,2 \mathrm{~mm}$ sebesar $8 \%, 0,2-1 \mathrm{~mm}$ sebesar $83 \%, 1-3 \mathrm{~mm}$ sebesar $7,95 \%$, 3-6mm sebesar $0,85 \%$ dan $>6 \mathrm{~mm}$ ada $0,2 \%$.

2. Pengadaan periode ahir Tahun 2017 hasil pengukuran menunjukkan ukuran $<0,2 \mathrm{~mm}$ sebesar $0,8 \%, 0,2-1 \mathrm{~mm}$ sebesar $32,75 \%, 1-3 \mathrm{~mm}$ sebesar $35,1 \%$, 3-6mm sebesar $24,9 \%$ dan $>6 \mathrm{~mm}$ sebesar $6,45 \%$.

3. Pengadaan periode awal tahun 2018 ukuran pasirnya $<0,2 \mathrm{~mm}$ sebesar 2,65\%, 0,2-1mm sebesar 20,15\%, 1-3mm sebesar 37,9\%, 3-6mm sebesar $35,75 \%$ dan $>6 \mathrm{~mm}$ sebesar $3,55 \%$.

4. Sedangkan pemeriksaan ukuran pada abu menjukkan hasil ukuran $<0,2 \mathrm{~mm}$ sebesar $23,25 \%, 0,2-1 \mathrm{~mm}$ sebesar $75,2 \%, 1-3 \mathrm{~mm}$ sebesar $0,8 \%$ dan selebihnya karena adanya campuran rontokkan refractory.

\section{Analisa Pemakaian Pasir}

Pemakaian pasir diharapkan seminim mungkin untuk penambahannya karena pasir yang digunakan adalah jenis pasir silica dimana titik melting di atas $1200^{\circ} \mathrm{C}$ sedangkan ruang bakar temperaturnya sekitar $850^{\circ} \mathrm{C}-950^{\circ} \mathrm{C}$, dengan demikian diharapkan pasir tidak terjadi meleleh dan tidak terjadi penurunan ukuran secara cepat. Tetapi karena pasir tersebut dibubbling sehingga terjadi gesekan maka pasir tersebut akan mengecil dan baru dilakukan penambahan jika volume pasir di dalam boiler mengalami penurunan. Jika pasir yang digunakan ukuran terlalu kecil maka mengakibatkan penggunaan pasir akan cenderung banyak karena pasir yang kecil ikut terbang akibat terbawa udara isap oleh IDF (Induce Draft Fan) bersama abu sisa pembakaran. Tetapi banyaknya penggunaan pasir ini tidak terlalu signifikan dibanding dengan faktor yang menimbulkan kerusakan pada refractory maupun kerusakan pada tubetube boiler.

\section{Analisa pengaruh pemakaian jenis dan ukuran pasir yang tidak tepat}

1. Kerusakan Refractory

Refractory dalam Boiler CFB merupakan pelindung terjadinya gesekan antara bahan bakar (pasir dan batubara) dengan tube. Selain sebagai pelindung gesekan juga merupakan isolasi terhadap udara luar. Kerusakan refractory faktor utama yang disebabkan oleh terjadinya gesekan dari pasir yang dibubling. Pergerakan pasir tersebut akan menggesek refractory yang mengakibatkan refractory abrasive.

Visual test dilakukan untuk mengetahui kondisi upnormal pada boiler (berdasarkan perubahan warna ataupun indikasi defect pada material). Ukuran tebal tube pada boiler PLTU Pulang pisau standar yang diijinkan adalah $5 \mathrm{~mm}$ dengan toleransi penipisan sebesar $25 \%$. Jadi bila dari hasil pengukuran terdapat ketebalan dibawah $5 \mathrm{~mm}-(5 \times 25 / 100) \leq 3.75 \mathrm{~mm}$, dianjurkan tube tersebut untuk dilakukan penggantian/repair.

\section{Kerusakan pada Tube Boiler}

Tube boiler jenis CFB kerusakan sebagian besar disebabkan dari sisi luar tube (gbr 4.6). Berbeda dengan jenis PC dimana kerusakan /penipisan disebabkan dari dalam tube. Boiler jenis CFB ini selain penipisan dari dalam tube akibat aliran fluida (berupa air dan atau uap) juga terjadi pengikisan/abrasive dari luar tube akibat gesekan dengan pasir campur bahan bakar (batubara).

Kerugian pada kerusakan tube ini sangatlah besar jika dihitung dari biaya penyediaan material, biaya perbaikan serta kerugian akibat tidak produksi. 
Jika kita ambil contoh menghitung kerugian akibat tidak produksi saja berdasarkan data outage dengan durasi paling cepat pemulihannya dari Tabel 4.5 yang terjadi kerusakan pada walltube, shutdown tanggal 12 Desember 2016 selama 163:34 jam beban $60 \mathrm{MW}$, jika harga jual energi listrik Rp 1.450/Kwh (asumsi) maka:

$$
\begin{aligned}
\text { Kerugian tidak produksi } & =\text { Daya } \times \text { waktu } \times \text { harga jual } \\
& =60.000 \mathrm{Kw} \times 163,57 \mathrm{jam} \times \mathrm{Rp} 1.450 \\
& =\mathrm{Rp} 14.230 .590 .000
\end{aligned}
$$

Kerugian tersebut di atas hanya dihitung dari faktor tidak produksi. Belum lagi ditambah biaya-biaya pembelian material/sparepart, alat serta jasa perbaikan yang nilai nominalnya juga tidak sedikit. Gambar 4.7 merupakan proses repair/penggantian wall tube boiler yang bocor.

\section{Tersumbatnya Saluran Udara Primer}

Penumpukan pasir pada saluran udara primer ini akan menjadi banyak sehingga suplay udara ke ruang bakar yang di kirim oleh PAF (Primary Air Fan) menurun. Hal ini pressure pada saluran udara primer meningkat yang bisa berakibat turunnya suplay udara pada sand bed material (pasir) dan pecahnya flexible joint.

Dari data yang diperoleh dengan beban berbeda dan ukuran pasir yang berbeda, akan terjadi perbedaan flow batubara dan tekanan udara saat masih menggunakan pasir acak sesuai manual book (ukuran 0-5 mm) yang tanpa batasan persentase ukuran, dengan menggunakan acuan yang kita buatkan variabel persentase ukuran. Data tersebut bisa kita lihat pada Tabel 4. Sebagai perbandingan dampak dari penggunaan ukuran pasir yang berbeda.

Tabel 4.Perbandingan dampak penggunaan ukuran pasir

\begin{tabular}{|c|c|c|c|}
\hline No & Uraian & $\begin{array}{c}\text { Tanpa variabel } \\
\text { tgl. 19/03/2016 }\end{array}$ & $\begin{array}{c}\text { Dengan variabel } \\
\text { tgl.18/10/2018 }\end{array}$ \\
\hline 1 & Ukuran pasir & $0-5 \mathrm{~mm}$ & $\begin{array}{c}\text { Variable antara 0-5 } \\
\mathrm{mm}\end{array}$ \\
\hline 2 & Tekanan udara pada air cap & $13,67 \mathrm{kpa}$ & $11,21 \mathrm{kpa}$ \\
\hline 3 & Tekanan udara bahan bakar & $13,67 \mathrm{kpa}$ & $10,76 \mathrm{kpa}$ \\
\hline 4 & $\begin{array}{c}\text { Deviasi tekanan udara: bahan } \\
\text { bakar dengan air cap }\end{array}$ & $0,165 \mathrm{kpa}$ & $0,445 \mathrm{kpa}$ \\
\hline 5 & Beban & $60,59 \mathrm{MW}$ & $50,45 \mathrm{MW}$ \\
\hline 6 & Coal flow & $51,7 \mathrm{t} / \mathrm{h}$ & $38,6 \mathrm{t} / \mathrm{h}$ \\
\hline 7 & SCC & $0,853 \mathrm{~kg} / \mathrm{kwh}$ & $0,765 \mathrm{~kg} / \mathrm{kwh}$ \\
\hline 8 & Flow PAF & $236598 \mathrm{~m}^{3} / \mathrm{h}$ & $179403 \mathrm{~m} / \mathrm{h}$ \\
\hline 9 & Flow SAF & $188737 \mathrm{~m}^{3} / \mathrm{h}$ & $134685 \mathrm{~m}^{3} / \mathrm{h}$ \\
\hline
\end{tabular}




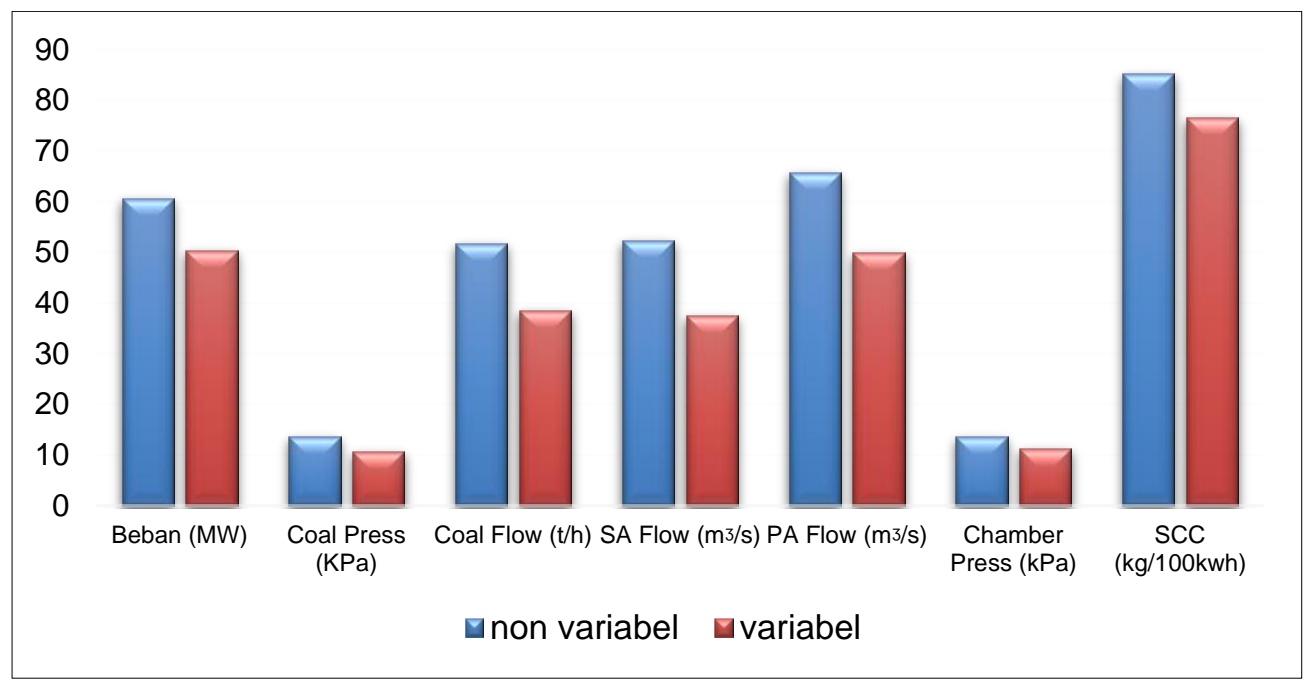

Gambar 3. Grafik Ukuran Pasir Berbeda Dengan Beban Berbeda

Catatan :

1. Warna biru ukuran pasir $0-5 \mathrm{~mm}$ tanpa batasan.

2. Warna merah ukuran pasir $0-5 \mathrm{~mm}$ dengan batasan variabel ukuran.

\section{Analisa Hubungan}

1. Hubungan antara ukuran pasir dengan tekanan udara primer

Ukuran material (pasir dan batubara) akan mempengaruhi terhadap tekanan udara primer. Bila kita perhatikan pada Tabel 2. bisa kita lihat selisih tekanan udara primer pada air cap untuk membubbling pasir yang telah menggunakan ukuran pasir yang tidak menentu yaitu sebesar $13,84 \mathrm{kPa}$, sedangkan yang menggunakan ukuran pasir ideal hanya 10,76 kPa. Memang dari segi beban berbeda tetapi untuk membuat pasir bubbling di area yang sama, seharusnya tidak perlu terlalu besar perbedaan tekanan pada air cap ini.

Bila ukuran pasir terlalu kecil maka tekanan udara primer yang diperlukan juga harus rendah. Tetapi bila tekanan udaranya rendah batubara yang terbakar tidak bisa maksimal karena tidak terjadi bubbling kurang bagus sehingga tidak terjadi fludisasi secara sempurna. Sedang bila tekanan udara primer dinaikkan maka pasir akan terjadi entrained yang akan mempercepat abrasive refractory serta pemakaian pasir kurang efektif karena banyak yang akan terbang ikut bersama abu.

Pasir ukuran lebih besar maka tekanan udara primer juga harus tinggi. Jika tekanan dinaikkan cenderung mempercepat abrasive pada refractory dan tube. Apa bila tekanan udara primer rendah maka akan terjadi hot spot di area bed karena tidak terjadi bubbling dan batubara yang terbakar tidak bisa sempurna sehingga temperature furnace tidak merata.

2. Hubungan antara tekanan udara primer dengan flow batubara

Udara primer selain digunakan sebagai pendorong sand bed material juga sebagai pendorong batubara yang keluar dari coal feeder menuju furnace agar coal flow bisa lancar sesuai yang diinginkan. Pengaturan udara pada coal flow ini harus sebanding dengan tekanan udara primer sebagai pendorong bed serta tekanan udara sekunder sebagai udara pebakaran. Dengan penyesuaian tekanan udara baik udara primer maupun udara sconder dengan flow batubara 
ini agar mendapatkan ratio pembakaran yang sempurna pada ruang bakar (Furnace).

3. Hubungan flow batubara dengan beban

PLTU umumnya yang menggunakan bahan bakar batubara, khususnya PLTU Pulang Pisau. Apabila flow batubara tidak bisa menyuplay dengan cukup maka beban unit tidak mampu menghasilkan beban $100 \%$. Flow batubara pada PLTU umumnya yang dipakai sebagai acuan perhitungan kinerja pembangkit, Oleh sebab itu selain flow juga jenis dan kandungan kalor yang ada pada batubara sangat dominan terhadap produksi.

4. Hubungan ukuran pasir, tekanan udara, flow batubara dan beban

Hubungan antara udara baik udara primer maupun udara seconder berkaitan dengan flow batubara terhadap beban. Bila ukuran pasir, jenis dan ukuran bahan bakar batubara, tekanan udara baik udara primer maupun udara seconder, serta flow batubara terjadi fluidisasi yang baik di ruang bakar maka terjadi pembakaran yang sempurna sesuai beban yang dikehendaki. Dengan demikian unit tersebut menjadi handal dan efisien.

Tabel 5. Data operasi dengan beban sama

\begin{tabular}{|c|c|c|c|c|c|c|}
\hline \multicolumn{3}{|c|}{ Data tanggal } & $20 / 06 / 2017$ & $17 / 01 / 2018$ & $11 / 06 / 2018$ & $13 / 08 / 2018$ \\
\hline \multicolumn{3}{|c|}{ Ukuran Pasir (mm) } & $0-5$ & $0.5-1.2$ & $2-5$ & $2-3$ \\
\hline \multicolumn{3}{|c|}{ Beban } & 50,7 & 50.91 & 51.09 & 50.14 \\
\hline \multicolumn{3}{|c|}{ Pemakaian pasir 1 bulan } & 135.54 & 24.62 & 61.1 & 38.28 \\
\hline \multirow{3}{*}{$\begin{array}{l}\text { Bed } \\
\text { layer }\end{array}$} & \multicolumn{2}{|c|}{ Temp } & 879 & 919.6 & 964.9 & 944 \\
\hline & \multirow{2}{*}{ Press } & $\mathrm{L}$ & 0.46 & 0.101 & 0.305 & 0.088 \\
\hline & & $\mathrm{R}$ & 0.614 & 0.239 & 0.388 & 0.215 \\
\hline \multirow{5}{*}{$\begin{array}{l}\text { PA } \\
\text { Fan }\end{array}$} & \multirow{2}{*}{$\begin{array}{c}\text { Open } \\
\text { damper }\end{array}$} & A & 26.08 & 40.21 & 42.25 & 48.3 \\
\hline & & B & 25.77 & 40.25 & 49.17 & 46.4 \\
\hline & \multirow[t]{3}{*}{ Flow } & A & - & 154322 & 195045 & 192145 \\
\hline & & $\mathrm{B}$ & - & 154322 & 195045 & 192145 \\
\hline & & $\begin{array}{l}\text { Total } \\
\text { Flow }\end{array}$ & - & 308644 & 390085 & 384290 \\
\hline \multirow{5}{*}{$\begin{array}{l}\text { SA } \\
\text { Fan }\end{array}$} & \multirow{2}{*}{$\begin{array}{c}\text { Open } \\
\text { damper }\end{array}$} & A & 37.9 & 55.21 & 32.09 & 33.13 \\
\hline & & $B$ & - & - & - & - \\
\hline & \multirow[t]{3}{*}{ Flow } & A & 157298 & 154322 & 124451 & 156759 \\
\hline & & $B$ & 157298 & 154322 & 124451 & 156759 \\
\hline & & $\begin{array}{l}\text { Total } \\
\text { Flow }\end{array}$ & 314596 & 308644 & 248902 & 313518 \\
\hline \multicolumn{3}{|c|}{ Coal Flow } & 39.9 & 43.6 & 49 & 42.2 \\
\hline \multicolumn{3}{|c|}{ SCC } & 0.78 & 0.85 & 0.95 & 0.84 \\
\hline
\end{tabular}

Dalam Tabel 5 merupakan varian penggunaan ukuran pasir dengan beban yang sama menyebabkan perbedaan pemakaian pasir, udara, dan bahan bakar. Data logsheet tanggal 20 Juni 2017 flow PAF belum tersedia dalam data logsheet, dengan bukaan damper yang rendah beban sudah bisa mencapai 50 MW. Tetapi dalam hal ini pemakaian pasir paling banyak bila dibandingkan dengan bulan yang lain. Disini mengGambarkan bahwa dengan pasir yang ukuran kecil dengan tekanan rendah maka pasir tersebut mudah terlempar yang cenderung terjadi gesekan terhadap refractory. 


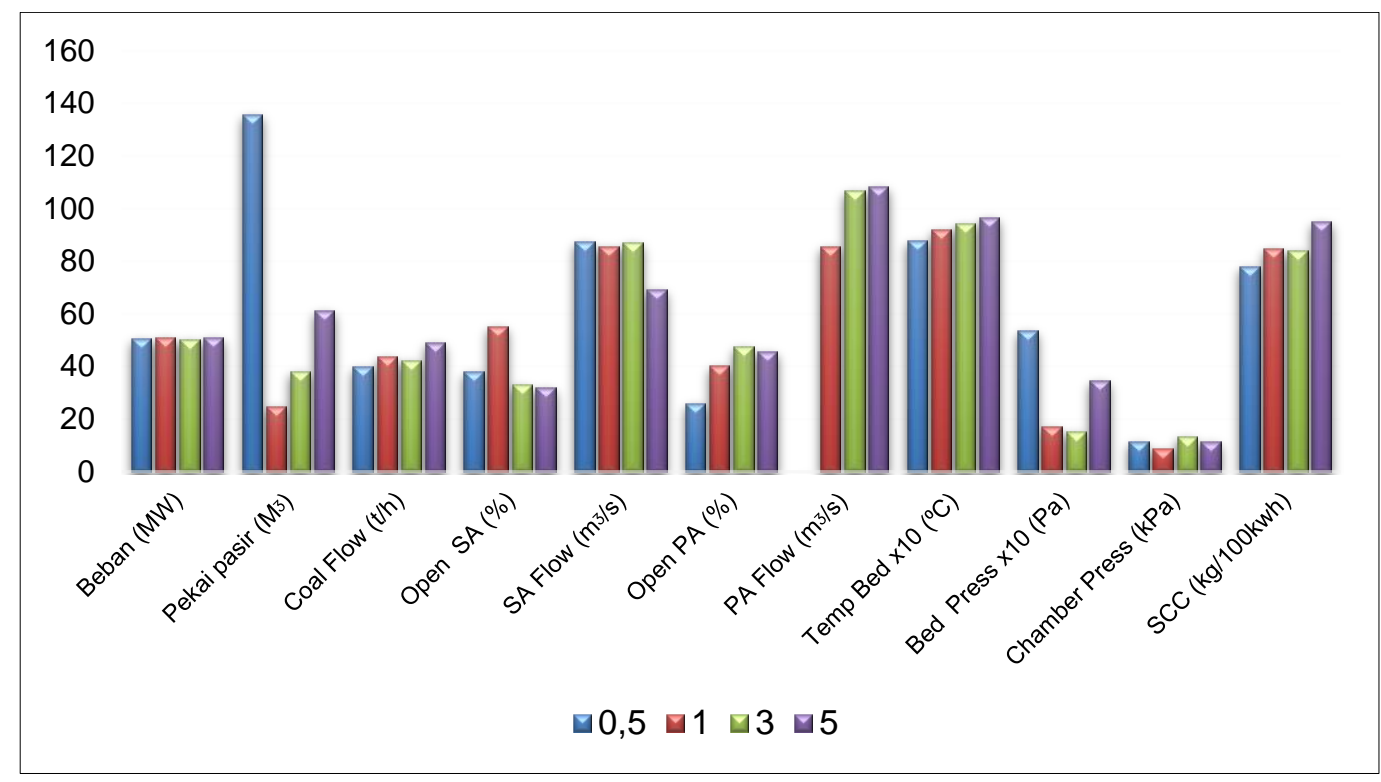

Catatan :

Gambar 4. Grafik Ukuran Pasir Berbeda Dengan Beban Sama

1. Warna : biru ukuran pasir $0-1 \mathrm{~mm}$, merah $1-2 \mathrm{~mm}$, hijau 2-3mm, ungu 4-5mm.

2. Flow PA fan dengan penggunaan pasir $0,5 \mathrm{~mm}$ saat mengambil data di logshet tidak tertulis.

Counter flow coal feeder saat itu belum dikalibrasi sehingga terlihat SCCnya baik $(0,78 \mathrm{~kg} / \mathrm{kwh})$, tetapi dari data stock opname batubara, stock batubara terjadi minus sehingga disimpulkan bahwa counter coal feeder saat itu datanya tidak akurat yang perlu dilakukan kalibrasi.

Dibandingkan dengan varian pasir yang berbeda maka bukaan damper yang ideal masing-masing sekitar $40 \%$ untuk mendapatkan flow dan tekanan yang tepat. Tabel 3. merupakan data yang diambil dari Logsheet berdasarkan beban yang mendekati sama dengan penggunaan ukuran pasir yang berbeda. Di dalam logsheet tersebut tidak mencantumkan tekanan pada batubara, berbeda dengan yang ditampilkan pada layar CCR (pada Tabel 4) pada monitor terdapat tekanan batubara yang masuk ke ruang bakar.

Setelah memperhatikan Gambar grafik 3 dan Gambar grafik 4. kinerja boiler unit 1 PLTU Pulang Pisau dengan variasi penggunaan ukuran pasir yang berbeda dengan beban berbeda serta penggunaan ukuran pasir yang berbeda dengan beban sama terdapat hala-hal antara lain:

a. Penggunaan ukuran pasir semakin kecil $(<1 \mathrm{~mm})$ keuntungannya SCC rendah (baik), tetapi dampaknya pemakaian pasir boros, tingkat abrasive pada refractory besar.

b. Penggunaan ukuran pasir yang besar $(4-5 \mathrm{~mm})$ keuntungannya adalah hemat pemakaian pasir. Tetapi dampak yang ditimbulkan tingkat panas yang dihasilkan kurang merata, yang cenderung terjadi hot spot pada layer bawah serta tingkat abrasivenya refractory tinggi, dan SCC tinggi.

c. Penggunaan ukuran pasir 2-3mm merupakan ukuran yang ideal karena kinerja yang dihasilkan masih standart, serta terhadap kehandalan unit (tingkat abrasive) paling baik dibandingkan dengan ukuran pasir yang lainnya. 


\section{KESIMPULAN}

Hasil dari penelitian dan pembahasan dapat disimpulkan, yaitu jenis dan ukuran pasir untuk mendapatkan pola operasi yang handal dan efisien, pada boiler unit 1 PLTU Pulang Pisau adalah menggunakan pasir jenis kwarsa warna putih bersih dengan ukuran antara $2-3 \mathrm{~mm}$.

\section{DAFTAR PUSTAKA}

Adi Setyono, Desember 2016, laporan pengujian ketebalan Tube pada furnace Left PLTU Asam asam unit 4.

Adid A. Hermansyah, Bambang Ismanto, Hafid. 2005. Analisis Kerusakan pipa superheater yang digunakan pada pipa boiler.

Anotana Telaumbanua, Ir. Tugiman ST "Analisa Fluidisasi pada Boiler CFB PLTU Labuhan Angin"

Astu Pudjanarsa \& Djati Nursuhud, 2012 "Mesin Konversi Energi" Andi.

Bambang Suwondo Rahardjo, Studi alih -fungsi CFB Boiler Sebagai Pembangkit Co Generation.

Chairul Saleh; Purnomo, Muhammad Ridwan Andi. 2013. Metodologi Penelitian. Dalam C. S. AP. Yogyakarta: Jaya Abadi.

Djiteng Marsudi, 2005, "Pembangkitan Energi Listrik", Erlangga.

M.NATSIR, dkk, Analisis keutuhan struktur bahan superheater PLTU Suralaya, Prosiding Presentasi Ilmiah Teknologi Keselamatan Nuklir VI, P2TKN BATAN, ISSN 14100533, Serpong 29 Maret 2001.

Rahmat Wicaksono 1), Mochammad Noer IIman 2) 2018 "Investigasi kebocoran Pipa Boiler pembangkit Listrik tenaga Uap 65".

Stephanus andry Cristanto, Ahmad Zayadi, dan Marsudi "Analisa Kerusakan Pipa Boiler untuk menentukan Program pemeliharaan lanjut"

Sumber Urip Agus Salim, Muslim Mahardika dan Aristo Taufiq "Simulation of Particle Flows of Circulating Fluidized Bed "2017.

http://www.wirahadie.com/2016/12/jenis-jenis-pembangkit-listrik.

https://ceritaboiler.blogspot.com/2016/08/pasir-silika-pada-boiler-fluidizedbed.html.

https://nasional.tempo.co/read/273832/pembangunan-pltu-di-kalimantan-tengahsegera-dimulai/full\&view=ok.

https://www.bps.go.id/dynamictable/2016/01/05/1110/kapasitas-terpasang-mwperusahaan-listrik-negara-pln-menurut-jenis-pembangkit-listrik-1995-2015. 